\title{
Role of Tumor Necrosis Factor Alpha and Transforming Growth Factor Beta as Predictive Marker for Psoriasis Patients
}

Tadamun H Adbullah (BSC) ${ }^{1}$, Ismail I Latif(PhD $)^{2}$ and Khudair Kh Ibrahim $(\mathrm{PhD})^{3}$

\begin{abstract}
Background: Psoriasis is a multifactorial and inflammatory skin disease. The etiology is not well. A large number of cytokines have been shown to be elevated in serum concentration and psoriatic lesion, and the elevation is correlate with psoriasis severity.

Objective: To evaluate TNF-a and TGF-B1 index in psoriasis which could help as predictive marker of severity of psoriasis in Baquba teaching hospital Iraq.

Patients and Methods: Forty nine patients with psoriasis (27male and 22 female) were included in this study. Their age range between (7-70) years old. The study was performed in Baquba Teaching Hospital during period from December 2018 to June 2019. Each case was diagnosed by Dermatologist.

Results: In our study we compare the mean, standard deviation and P. value of TNF-a and TGF-B in patients of psoriasis. We have found that psoriasis patients have a highly significant difference compared to controls $(\mathrm{P}=0.001)$ in both genders.

Conclusion: This study concludes a significant association between tumor necrosis factor alpha and transforming growth factor beta-1 in psoriasis patients in both gender.

Keywords: Psoriasis, Tumor necrosis factor alpha, Transforming growth factor beta-1.

Corresponding Author: lamaralkasiy489@gmail.com

Received: $15^{\text {th }}$ October 2019

Accepted: $26^{\text {th }}$ November 2019

DOI:https://doi.org/10.26505/DJM.19015031015

\section{Introduction}

${ }^{1,2,3}$ College of Medicine -Diyala University- Diyala- Iraq

Psoriasis is an autoimmune disease characterized by chronic and recurrent inflammatory skin disease with approximately1.3-2.2\% prevalence all over the world[1].The innate and adaptive immune response responsible for chronic inflammation of the skin [2].Plaque psoriasis is the most common clinical manifestation

and its features include red scaly plaques lesion on the scalp, elbows, knee. Less common types of psoriasis including psoriatic erythroderma, nail, pustular psoriasis and psoriatic arthritis are usually thought to be more severe entities of psoriasis [3].Psoriasis is multifactorial disorder characterized by trauma, injury,
\end{abstract}


Role of Tumor Necrosis Factor Alpha and Transforming Growth Factor Beta as Predictive Marker for

Psoriasis Patients

medication and infection as well as psychology stress [4]. $\mathrm{T}$ cell mediated inflammatory pathology, cells that belong to both innate and adaptive immunity as well as non-immune cells are highly involved. Thus from the first category, dendritic cells, NK cells and macrophages were found as being involved in the pathogenesis of psoriasis, along with cells from the second category; namely keratinocytes and endothelial cells [5].

Once activated, dendritic cells are transformed into mature antigen presenting cells and start producing cytokines like TNFa, IL-23 and IL-12 and are therefore able to interact with $\mathrm{T}$ naive cells. IL-23, in association with IL-6 and TGF-B1,will determine the transformation of CD4+ naive cells to Th-17 which will produce IL-17, IL22 and TNF-a, IL-23 in association with IL-6 and TNF-a also promotes the production of Th-22 cells which secrete IL-22 and TNF$\mathrm{a}[6]$.

Tumor Necrosis Factor-alpha is type of cytokine responsible for a enigmatic cytokine psoriasis pathogenesis; although it is produced by most activated DCs, T cells, NK cell, macrophages, monocytes, Langerhans APC, endothelial cells and keratinocytes. It is considered an upstream cytokine in the IL-23 and IL-17 pathway, acting as inducer of IL-23 production by DCs $[7,8,9]$.

Transforming growth factor beta-1is a multi-potent growth factor involved in maintaining immune homeostasis. It inhibits the activity of macrophages and neutrophils, promotes angiogenesis and the proliferation of fibroblasts and regulates $\mathrm{T}$ cells subpopulations [10]. Transforming growth factor $\beta$ (TGF $\beta)$ is a multi-potent cytokine that regulates both cell growth and differentiation. Studies showed that elevated serum levels of TGF-B1 are found in psoriatic patients and that those levels are correlated with disease severity [11].

This study was conducted to evaluate TNFa and TGF-B1 index in a sample of psoriasis patients which could help to predict the diagnosis psoriasis in Baquba Teaching Hospital, Iraq.

\section{Patients and Methods}

This case control study included (49) patient with psoriasis (27males and 22 females). Their ages range between (7-70) years old. The study was performed at Baquba Teaching Hospital during period from December 2018 to June 2019. The diagnosis in each case was established by Dermatologist. (33) healthy control included 18 males and 15 females selected randomly from school, college and worker, their age range from (10-68) years. Questionnaire on personal information was prepared. The data for each participant were obtained. These included: age, gender, family history, occupation, type of treatment, type of psoriasis, duration, other disease. Five milliliter of venous blood samples were obtained from each person (patients and healthy groups) placed $(3 \mathrm{ml})$ in gel tube and (2ml) put in EDTA tube for WBC and differential count, recorded directly from Hematological indices. After coagulation at 
Role of Tumor Necrosis Factor Alpha and Transforming Growth Factor Beta as Predictive Marker for

Psoriasis Patients

room temperature sera were separated by centrifuge $4000 x g$ for 15 minutes. After that divides the serum in to four eppendorf tube and directly stored at $-80{ }^{\circ} \mathrm{C}$ to be analyzed later for serum transforming growth factorbeta1 and tumor necrosis factor-alpha. The level of TNF-a and TGF-B1 (Human TNFa\&TGF-B1, 2 Elisa kit supplied by Sinogeneclon BiotechCo., Ltd, China) was measured with the serum using the sandwich enzyme-linked immunosorbent assay (ELISA) method. White blood cell (WBC), neutrophil, lymphocyte, monocyt, eosinophil and basophil counts were measured by an automated blood cell counter (Hematology Analyzer. Germany).

\section{Statistical analysis}

Data of current study were analyzed by using Chi-square (X2) test to compared between percentages. Numeric date were described by (Mean \pm SD). $T$ test used to compare between two numeric variables, while $\mathrm{F}$ test (ANOVA) used to compared between three numeric variables or more. Pearson correlation ( $\mathrm{R})$ accounted to explain type and strength of relationship between variables. $P$ value equal or less than $(0.05)$ was applied to test. Using SPSS version (21) statistical peak age of social science version.

\section{Results}

Forty nine patients with psoriasis (27 males and 22 females) and thirty three healthy individuals (18males and 15 females) were included in the study. The mean age of patients and control were $32.14 \pm 16.16$ and $33.57 \pm 15.27$ years respectively with insignificant difference at $(\mathrm{P}=0.59)$. Also for gender, there was no significance difference in the frequency for patient $(\mathrm{P}=0.57)$. The family history of psoriasis was $(24.5 \%)$ in patients while(75.5\%) negative. $89.8 \%$ of patients consisted psoriasis vulgaris ,4.1\% erythrodermic and $6.1 \%$ (nail and Guttat).. Fourteen of patients were diabetic and hypertensive(14.6) and (6.10\%) had psychological illness $(\mathrm{P}=0.01)$ to Table $(1)$.

Table (1): Demographic data of patient and control groups, and comparison of age, gender, family history ,type of psoriasis and diseases association with psoriasis

\begin{tabular}{|c|c|c|c|}
\hline Groups & patient $(n=49)$ & control $(n=33)$ & P. value \\
\hline age, mean \pm SD & $32.14 \pm 16.16$ & $33.57 \pm 15.27$ & 0.59 \\
\hline Gender $\mathrm{n}(\%)$ & $\begin{array}{c}\text { mal 55.1\% } \\
\text { Female } 44.9 \%\end{array}$ & $\begin{array}{l}54.5 \% \\
45.4 \%\end{array}$ & 0.57 \\
\hline Family history & $\begin{array}{l}\text { Positive }(24.5 \%) \\
\text { Negative }(75.5 \%)\end{array}$ & 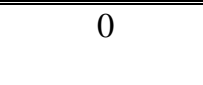 & 0.001 \\
\hline Type & $\begin{array}{c}\text { plaque }(89.8 \%) \\
\text { Erythrodermic }(4.1 \%) \\
\text { Nail and Gutat }(6.1 \%)\end{array}$ & 0 & 0.96 \\
\hline disease & $\begin{array}{c}\text { Without disease } \\
82.97 \% \\
\text { Diabetic and hypertension } 14.6 \% \\
\text { Psychological illness } 6.10 \%\end{array}$ & $\begin{array}{l}0 \\
0 \\
0\end{array}$ & 0.01 \\
\hline
\end{tabular}


Role of Tumor Necrosis Factor Alpha and Transforming Growth Factor Beta as Predictive Marker for

Psoriasis Patients

Table (2) shows immunological parameters differential within study groups. The result demonstrates very high significant difference in
TNF-a and TGF-B1 between patients and controls $(\mathrm{P}=0.001)$.

Table (2): Shows the TGF-B1 and TNF-a concentration in study groups

\begin{tabular}{|c|c||c|c|c|c||}
\hline Markers & Groups & Number & Mean & Std. deviation & p. value \\
\hline \hline \multirow{2}{*}{ TNF-a } & Patients & 49 & 52.63 & 15.53 & \multirow{2}{*}{0.001} \\
\cline { 2 - 5 } & Controls & 33 & 5.01 & 1.65 & \\
\hline \hline \multirow{2}{*}{ TGF-B1 } & Patients & 49 & 52.63 & 15.53 & \multirow{2}{*}{0.001} \\
\cline { 2 - 5 } & Controls & 33 & 7.90 & 7.69 & \\
\hline
\end{tabular}

This study showed no significant difference in the Neutrophils $(\mathrm{P}=0.88)$, Lymphocytes $(\mathrm{P}=0.22)$, Eosinophil's $(\mathrm{P}=0.24)$ and Basophils $(\mathrm{P}=46)$. While the monocytes found very high significant difference between patients and controls $(\mathrm{P}=0.007)$.

Table (3): Shows the WBC concentration in study groups

\begin{tabular}{|c|c|c|c|c|c|}
\hline WBC & Groups & Number & Mean & Std. deviation & p. value \\
\hline \multirow{2}{*}{$\begin{array}{c}\text { Neutrophils } \\
* 10^{9} / \mathrm{L}\end{array}$} & Patients & 49 & 5.86 & 0.97 & \multirow[t]{2}{*}{0.88} \\
\hline & Controls & 33 & 5.89 & 0.9 & \\
\hline \multirow{2}{*}{$\begin{array}{c}\text { Lymphocytes } \\
* 10^{9} / \mathrm{L}\end{array}$} & Patients & 49 & 2.96 & 0.74 & \multirow[t]{2}{*}{0.22} \\
\hline & Controls & 33 & 3.27 & 0.75 & \\
\hline \multirow{2}{*}{$\begin{array}{c}\text { Monocytes } \\
* 10^{9} / \mathrm{L}\end{array}$} & Patients & 49 & 0.82 & 0.20 & \multirow[t]{2}{*}{0.007} \\
\hline & Controls & 33 & 0.70 & 0.16 & \\
\hline \multirow{2}{*}{$\begin{array}{l}\text { Eosinophil's } \\
* 10^{9} / \mathrm{L}\end{array}$} & Patients & 49 & 0.23 & 0.16 & \multirow[t]{2}{*}{0.24} \\
\hline & Controls & 33 & 0.19 & 0.14 & \\
\hline \multirow{2}{*}{$\begin{array}{c}\text { Basophils } \\
* 10^{9} / \mathrm{L}\end{array}$} & Patients & 49 & 0.03 & 0.01 & \multirow[t]{2}{*}{0.46} \\
\hline & Controls & 33 & 0.03 & 0.01 & \\
\hline
\end{tabular}

\section{Discussion}

Although psoriasis is recognized as a disease involving the immune system, its etiology is not known exactly $[12,13]$. The major finding of the present study is that there was a highly significant association between psoriasis and cytokine levels of TNF-a and TGF-B1 were significantly higher in psoriasis patient than in controls. In the present study, serum levels of TNF- $\alpha$ in patients with psoriasis were significantly higher when compared with healthy controls. Our data are agreement with previous studies, which demonstrated increased TNF$\alpha[14,15]$.
A major finding of the current study is that the anti-inflammatory profile (TGF- $\beta$ ) is significantly elevated in psoriasis. The current result results revealed that the levels of TGF- $\beta 1$ were significantly higher in patients than the corresponding levels in controls. This result in agreement with Several investigators found higher levels of TGF- $\beta 1$ in patients with psoriasis than controls[16,17].

Unlikely,other investigators[18]found that TGF- $\beta 1$ levels are higher in serum of psoriatic patients in comparison to controls but insignificant. Our data are not agreement 
Role of Tumor Necrosis Factor Alpha and Transforming Growth Factor Beta as Predictive Marker for

Psoriasis Patients

with a previous study that demonstrated lowered levels of TGF- $\beta 1$ in patients with psoriasis than controls $[19,20]$.

While the WBC in our result were the neutrophils and lymphocytes counts in current study revealed no significant difference between the patient and $\operatorname{controls}(\mathrm{P}=0.88) \quad$ and $(\mathrm{p}=0.22)$ respectively which consistence with[21]. While the monocyte in our result shows significantly higher in patient than healthy control $(\mathrm{P}=0.007)$ Similar findings were also reported in a study in USA [22].On the other hand found study in china the monocytes in patients with psoriasis were significantly lower than the healthy controls [23]. In addition,the eosinophil's and basophils in current study shows insignificant difference between patient and $\operatorname{control}(\mathrm{p}=0.24)$ and $(\mathrm{p}=0.46) \quad$ respectively agree with previous study in Korea [24].

\section{Conclusions}

This study shed light on the psoriasis by investigating the relationship between pro and anti-inflammatory cytokines. We suggest that increased levels of TNF-a and TGF-B1 can be used as a predictive marker of psoriasis and disease severity.

\section{References}

[1]Parisi R, Griffiths CEM, Ashcroft DM. Systematic review of the incidence and prevalence of psoriasis. Br. J. Dermatol. 2011; 165:e5.

[2]Melikoglu M. Sleep Quality and its Association with Disease Severity in Psoriasis. Eurasian J Med. 2017;49(2):124. [3]Griffiths CE, Barker JN. Pathogenesis and clinical features of psoriasis. Lancet. 2007;370(9583):263-271.

[4]Ogawa E, Sato Y, Minagawa A, Okuyama R. Pathogenesis of psoriasis and development of treatment. J Dermatol .2018;45(3):264-72. [5]Caruntu C, Boda D, Dumitrascu G, Constantin C, Neagu M. Proteomics focusing on immune markers in psoriatic arthritis.

Biomark. Med. 2015; 9(6): 513-528.

[6]Surcel M, Huica R, Constantin C, Ursaciuc $\quad C, \quad N e a g u \quad M$. Biomarkers Insights in Psoriasis-Regulatory Cytokines. Curr. Biomark. 2018;7(1): 311.

[7]Chiricozzi A, Guttman-Yassky E, Suarez-Farinas M, Nograles KE, Tian S, Cardinale I, Chimenti S, Kru eger JG , Integrative responses to IL-17 and TNFalpha in human keratinocytes account for key inflammatory pathogenic circuits in psoriasis. J. Investig. Dermatol. 2011; 131(3): 677687.

[8]Johnston A, Fritz Y, Dawes SM, Diaconu D, Al-Attar PM, Guzman AM,Ward NL. Keratinocyte overexpression of IL-17C promotes psoriasiform skin inflammation. J Immunol. 2013; 190(5):2252-62.

[9]Hartupee J, Liu C, Novotny M, Li X, Hamilton T. IL-17 enhances chemokine gene expression through mRNA stabilization. J Immunol. 2007; 179:4135-41. [10]Owczarczyk-Saczonek A,Czerwi nska J, Placek $\mathrm{W}$. The role of regulatory $\mathrm{T}$ cells and anti-inflammatory cytokines in psoriasis.Acta Dermatovenerol. Alp. Panonica Adriat. 2018; 27(1): 17-23. 
Role of Tumor Necrosis Factor Alpha and Transforming Growth Factor Beta as Predictive Marker for

Psoriasis Patients

[11]Al-Shobaili H. Serum vascular endothelial growth factor, transforming growth factor1, and nitric oxide levels in patients with psoriasis vulgaris: Their correlation to disease severity. J. Clin. Lab.Anal. 2014;28(6):496-501.

[12]Slominski A, Zbytek B, Nikolakis G, Manna P R, Skobowiat C, Zmijewski M,Tuckey RC. Steroidogenesis in the skin: implications for local immune functions. J Steroid Biochem Mol Biol. 2013;137:107-23.

[13]Hannen R, Udeh-Momoh C, Upton J, Wright M, Michael A, Gulati, A, Flower R. Dysfunctional Skin- Derived Glucocorticoid Synthesis Is a Pathogenic Mechanism of Psoriasis. J Invest Dermatol. 2017;137(8):1630-7.

[14]Dowlatshahi EA, van der Voort EAM, Arends LR, Nijsten T. Markers of systemic inflammation in psoriasis: a systematic review and meta-analysis. $\mathrm{Br} \mathrm{J}$ Dermatol. 2013;(2)169:266-82.

[15]Campanati A, Orciani M, Lazzarini R, Ganzetti G, Consales V, Sorgentoni G, Offidani A. TNF- $\alpha$ inhibitors reduce the pathological Th 1-Th 17 /Th 2 imbalance in cutaneous mesenchymal stem cells of psoriasis patients. Exp Dermatol. 2017;26(4):319-24.

[16]Nockowski P, Szepietowski JC, Ziarkiewicz M, Baran E. Serum concentrations of transforming growth factor beta 1 in patients with psoriasis vulgaris. Acta Dermatovenerol Croat 2004;12(1):2-6. [17]Kallimanis PG, Xenos K, Markantonis SL, et al. Serum levels of transforming growth factor-betal in patients with mild psoriasis vulgaris and effect of treatment with biological drugs. Clin Exp Dermatol 2009;34(5):582-586.

[18]Zaher H, ShakerOG, EL-Komy MH, ElTawdiA, Fawzi M,Kadry D. Serum and tissue expression of transforming growth factor beta psoriasis. J Eur Acad Dermatol Venereol 2009;23(4):406-409.

[19]Doi H, Shibata M-A, Kiyokane K, Otsuki Y. Downregulation of TGFbeta isoforms and their receptors contributes to keratinocyte hyperproliferation in psoriasis vulgaris. J Dermatol Sci. 2003;33(1):7-16.

[20]Cataldi C, Mari NL, Lozovoy MAB, Martins LMM, Reiche, EMV, Maes M and Dichi I. Proinflammatory and antiinflammatory cytokine profiles in psoriasis: use as laboratory biomarkers and disease predictors. Inflammation Research.2019; 68(7):557-567.

[21]Gruchała A, Cisłak A, Golański J. Neutrophil-lymphocyte ratio and platelet-lymphocyte ratio as an alternative to $\mathrm{C}$-reactive protein in diagnostics of infl ammatory state in patients with psoriasis. Our Dermatol Online. 2019;10(1):7-11. [22]Wang Y, Edelmayer R., Wetter J, Salte K, Gauvin D, Leys L, Paulsboe S, Su Z, Weinberg I, Namovic M and Gauld SB.Monocytes/Macrophages play a pathogenic role in IL-23 mediated psoriasis-like skin inflammation. Sci. rep.2019; 9(1): 5310.

[23]Zhou Z, Chen J, Hong Y. Relationship Between the Serum Total Bilirubin and 
Inflammation in Patients With Psoriasis

Vulgaris.Cli.lab.ana.J. 2016.30(5):768-775.

[24]Kim DS, Shin D, Lee MS, Kim HJ, Kim

DY, Kim SM, Lee M G. Assessments of neutrophil to lymphocyte ratio and platelet to lymphocyte ratio in Korean patients with psoriasis vulgaris and psoriatic arthritis. J Dermatol. 2016;43(3):305-1024. 